\title{
Effectiveness of air-well type courtyards on moderating thermal environments in tropical Chinese Shophouse
}

\author{
Wajishani Gamage ${ }^{\mathrm{a}}$, Stephen Lau ${ }^{\mathrm{b}}$, Hao Qinc and Zhonghua Gou ${ }^{\mathrm{d}}$
}

a Department of Architecture, University of Moratuwa, Moratuwa, Sri Lanka; ${ }^{\circ}$ Department of Architecture, National University of Singapore, Singapore,

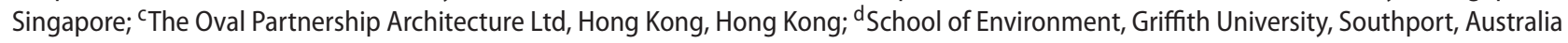

\begin{abstract}
In Southeast Asia with tropical climates, Chinese Shophouse (CSH) as a type of vernacular architecture is usually equipped with small intermediate air-well type courtyards, also known as 'Tianjin', to moderate the indoor thermal environment. This paper investigates the effectiveness of air-well type courtyards as passive design strategies on moderating indoor thermal environments in two CSHs located in Malacca, Malaysia. The study used a field survey and a CFD simulation. Statistical analyses of indoor air temperature and heat index (HI) measured at different locations of the CSHs show that intermediate spaces next to the air-wells had significantly lower air temperature and $\mathrm{HI}$. Cross ventilation through the openings on the walls and air-wells resulted in a significantly lower normalized mean age of air and higher air velocity. The air-well is a suitable passive design strategy to reduce overheating during daytime and to increase cooling of building structure during night-time. The air-well courtyards should be arranged in alignment with the prevailing wind to maximize the cross ventilation and passive cooling.
\end{abstract}

\section{ARTICLE HISTORY}

Received 16 May 2017

Accepted 17 September 2017

\section{KEYWORDS}

Thermal environment; air-well courtyard; Chinese Shophouses; passive cooling; energy efficiency

\section{Introduction}

In tropical climates cooling and dehumidification accounts for a major portion of energy consumptions in buildings (Kubota and Toe 2008). Traditionally natural ventilation has been widely used in tropical vernacular architecture to regulate the indoor thermal environments (Givoni 1998). The main climatic concern for buildings in tropics is high temperature, humidity and solar radiation (Olgyay 2015). The core temperature of the human body is maintained at a particular set point through various physiological processes managed by the hypothalamus (Bluyssen 2013). Under warm conditions vasodilation increases blood flow to the skin which results in sweating; if ambient humidity is also high, discomfort occurs due to skin wetness. Therefore, in hot humid climates increasing ventilation helps enhance sweat evaporation by removing saturated ambient air. Higher air velocities also provide a psychological cooling effect to occupants and reduce the discomfort caused by the subjective feeling of skin wetness. Therefore, tropical vernacular architecture adapts scatter building layouts to increase wind induced ventilation (Olgyay 2015). The depth of a building has a significant impact on the effectiveness of natural ventilation. For single-sided ventilation, the effective depth for natural ventilation is approximately twice the floor to ceiling height and for cross ventilation the effective depth is up to five times the floor to ceiling height (CIBSE 2005). These passive design principles advocate a narrow floor plan for naturally ventilated buildings.

The Chinese Shophouse (CSH) is a popular vernacular housing form found in the old cores of tropical port cities in Southeast Asia (Figure 1). The main design characteristic of a shophouse is a narrow frontage, deep rears, five-foot-wide covered walkway at the front and small internal courtyards. The width is approximately 4-6 $m_{1}$ while the length could be around 30-36 m(Hassan and Yahaya 2012). The primary ventilation openings of a CSH are located at front and rear walls (Wang and Jia 2016). Natural ventilation in this deep and compact house type is assisted by a small courtyard type termed as 'Tianjin' also known as 'airwell' or 'sky-well' (Hassan and Yahaya 2012). These air-wells are used between the functional spaces. Their verticality exceeds their horizontal dimension to avoid excessive solar radiation. The area percentage of an air-well on the footprint of a CSH is approximately 5-7\% (Knapp and Ong 2013). The functional spaces of a CSH are symmetrically organized with an axis across several air-wells and divided vaguely by non-structural partitions or airwells. In contrast to the accepted passive design principles in tropical climates, CSHs are typically arranged in a dense row layout (Firley and Stahl 2009) (Figure 1) (Figure 2).

The air-well type courtyard found in the Southeast Asian CSHs has been identified as a fine component of vernacular architecture which extracts passive techniques to moderate the indoor thermal environment (Zakaria, Kubota, and Toe 2015). The passive performance of an indoor courtyard in a tropical climate is primarily dependent on shading and ventilation (Hoseini et al. 2014). In hot humid climates, increased ventilation attributed to indoor courtyards can enhance sweat evaporation and physiological cooling of the building occupants. Increasing nocturnal air exchange accelerates the cooling of high thermal mass structure of a building. This will consequently result in lower indoor air temperatures during afternoon peak hours (Givoni 1998). Ventilation and infiltration during night and morning hours is the most favourable strategy to increase structural cooling of high 


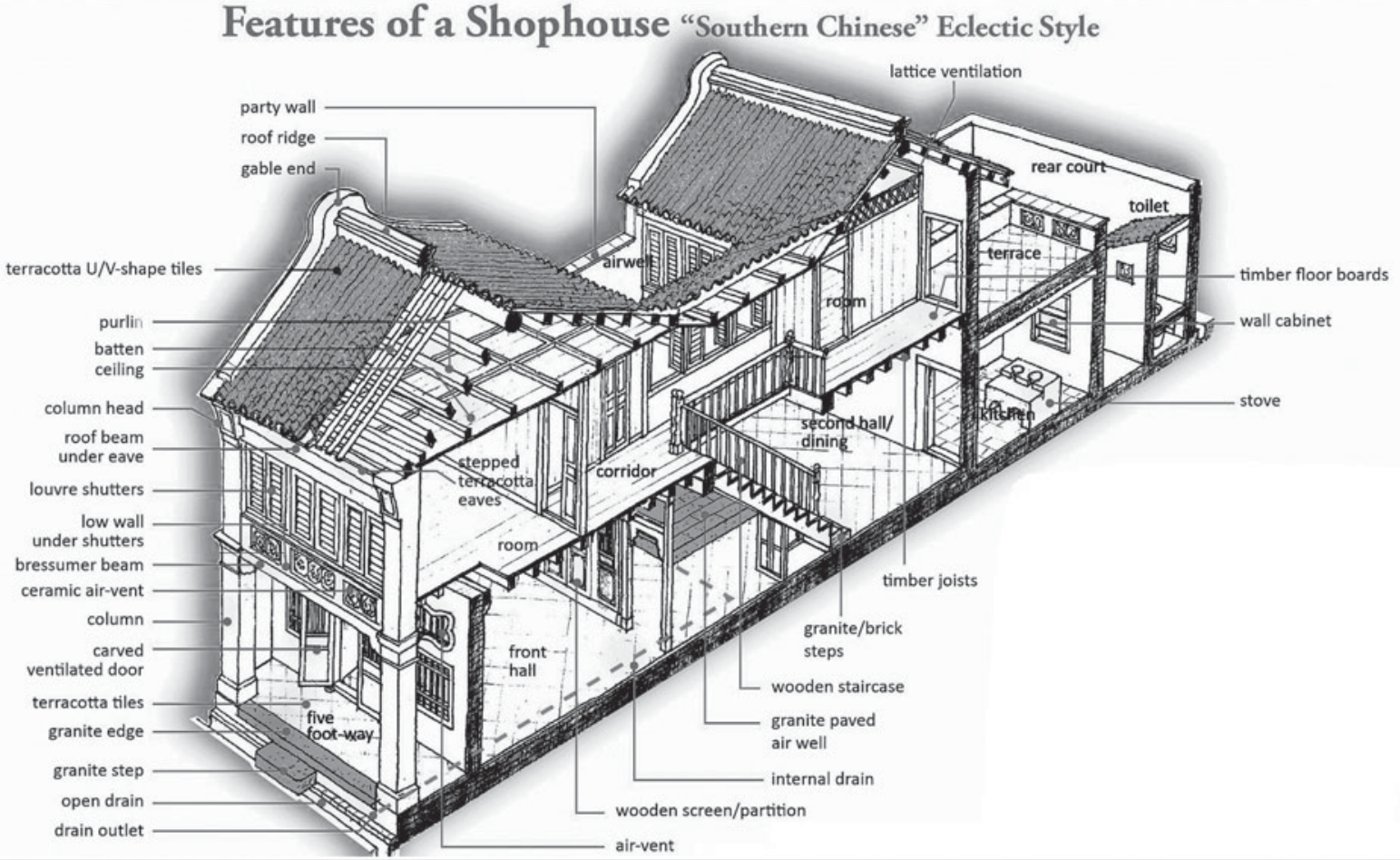

Figure 1. A typical Chinse Shophouse in Penang, Malaysia (by courtesy of Wang and Jia 2016).

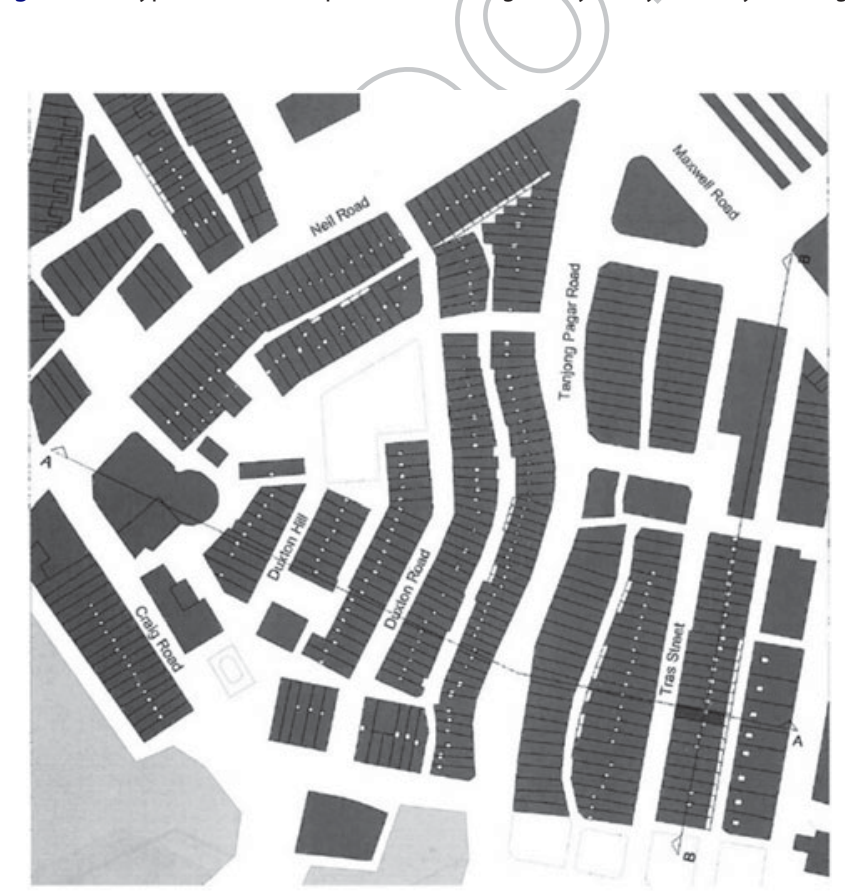

Figure 2. Street layout of Chinse Shophouses in Singapore (adapted from Firley Q13 and Stahl 2009).

thermal mass materials in tropical climates (Sadafi et al. 2011). Air-well type courtyards used in CSHs that have a height to width ratio greater than 0.65 may be considered sheltered from the direct impact of prevailing winds perpendicular to its axis (Jayasinghe and Attalage 1999). Therefore, these types of courtyards may not be able to fully harness the passive cooling attributes related to wind induced ventilation in the tropics. However, pervious research demonstrated that the use of multiple connected

air-wells with staggered form, i.e. courtyards situated between buildings of different heights, was able to improve cross ventilation and to increase indoor air velocity of intermediate spaces in the CSH with deep plan (Kubota et al. 2017).

Ventilation could also result from the stack effect. Stack effect is the movement of air due to the difference of indoor and outdoor air density as a result of temperature and moisture differences (Khanal and Lei 2011). In architecture, stack effect could come from the variation of temperature in courtyards and the outdoors. As outdoor air temperature tends to be lower than indoors at night-time, higher temperatures in courtyards than the outdoors can enhance the stack effect at night-time (Rajapaksha, Nagai, and Okumiya 2003). Toe and Kubota (2015) demonstrated the stack effect in air-well type courtyards in the $\mathrm{CSH}$ (Figure 3). At night-time, cooled air from the air-well opening flow into the building and cool the internal high thermal mass structure. During daytime, shading from direct and diffused radiation in the air-wells help to retain the cool air at lower level for a longer time period. Less-heated air at lower levels of the air-well prevented vertical air exchange with hot outdoor air. This results in lower indoor air temperature during daytime peak hours. In tropical climates as larger and shallower courtyards result in more heat gain and higher indoor air temperatures of adjacent spaces during the afternoon peak hours, deeper and more elongated courtyards with higher shading percentage is preferable (Martinelli and Matzarakis 2017). In these regions, the shading of the courtyard is mainly dependent on its depth rather than its elongation (Muhaisen 2006). A comparison study of thermal environments in 16 air-well courtyards in Malacca reveals that daily maximum air temperature in the air-well is mainly influenced by its openness and depth (Kubota et al. 2017). Closed and deep air-wells with higher shading were 

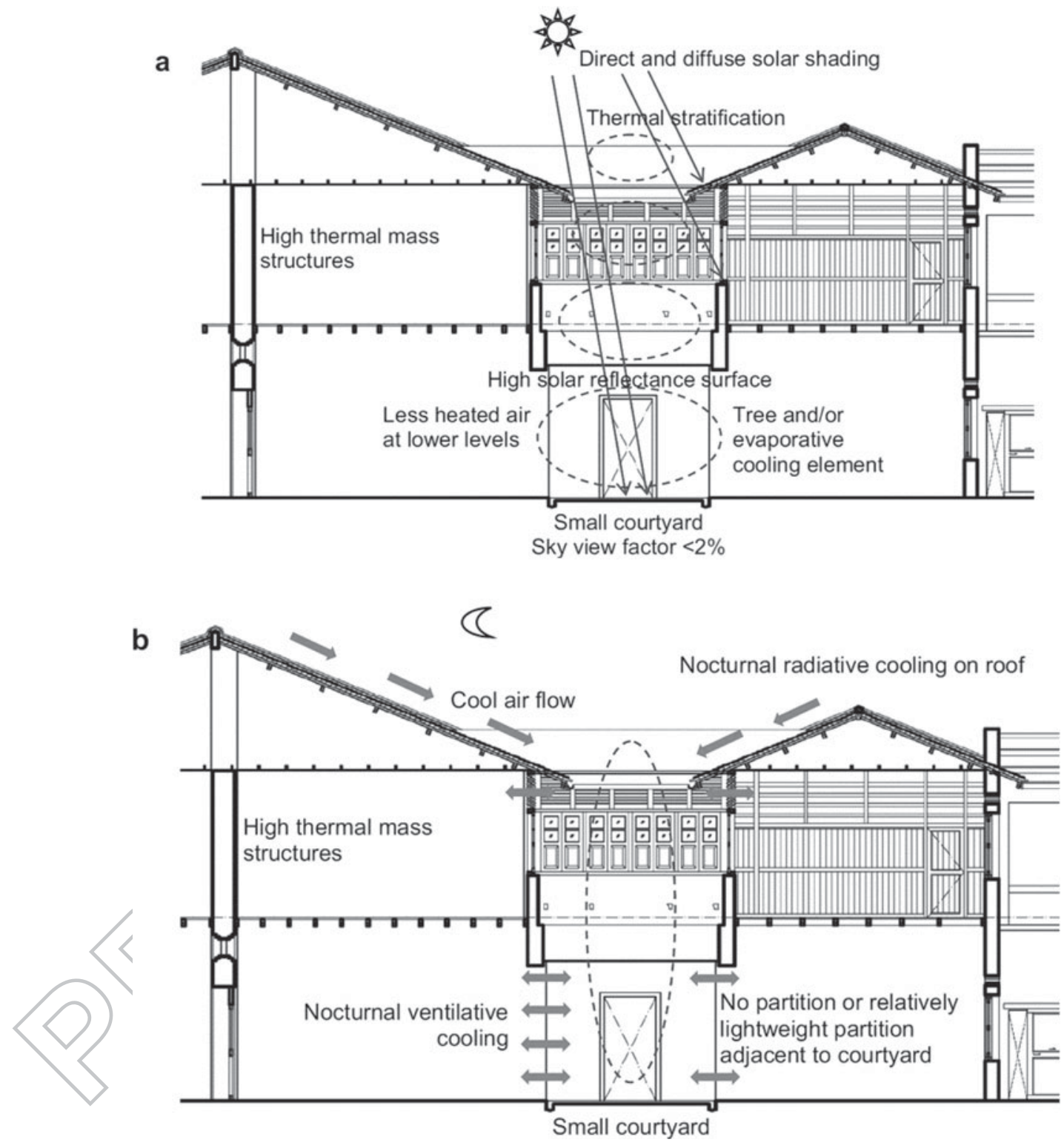

Figure 3. Conceptual illustrations of passive cooling by air-well type courtyard: (a) daytime and (b) night (adapted from Toe and Kubota 2015).

able to maintain lower indoor air temperatures during daytime peak hours.

The air-well type courtyards used in the Southeast Asian CSHs compliments its long narrow form. These air-wells have some features which are climatically appropriate for the hot humid regions, as well as some features which may hinder the optimum thermal comfort performance of an indoor courtyard in this climate. Research is needed to understand the effectiveness of the air-well type courtyard on moderating indoor thermal environment in these tropical CSHs. This study uses a filed investigation to explore variations of indoor thermal environment attributed to air-well courtyards in CSHs. Furthermore, a CFD (Computer Fluid Dynamics) simulation is used to investigate the impact of prevailing wind on passive cooling potential of the air-well courtyards.

\section{Methodology}

\section{The city of Malacca and selected shophouses}

Malacca is a tropical city located at $2^{\circ} 11^{\prime} 45^{\prime \prime} \mathrm{N}, 102^{\circ} 14^{\prime} 25^{\prime \prime} \mathrm{E}$. According to the city's weather record, climate variables, such as temperature and relative humidity, do not show large monthly variations (Toe and Kubota 2015). However, many variables exhibit prominent diurnal variations from hour to hour, indicating the strong influence of solar radiation on the local climate. The seasonal climatic change is dominated by the monsoons.

Malacca was once a small and remote fishing village and began to develop as a port city in the fourteenth century. Many CSHs which date back to the seventeenth and eighteenth century can be found within the core zone of this historic city. Several categories of CSHs' are found in Malacca, and their spatial 


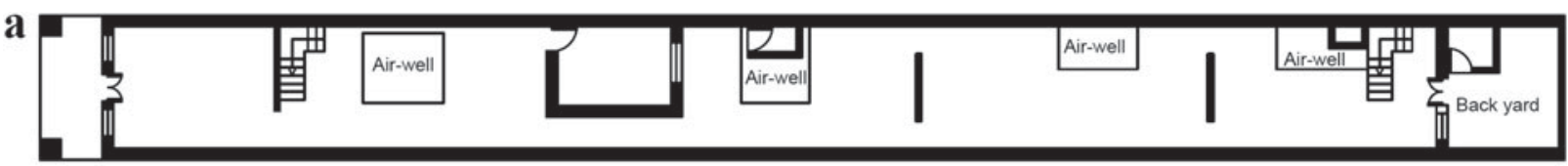

b

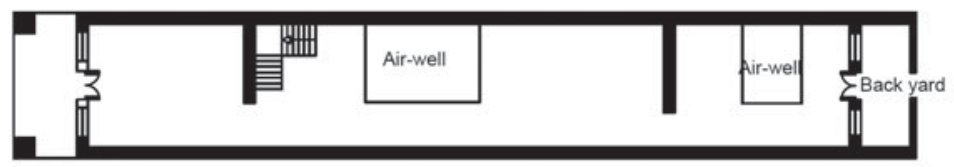

c

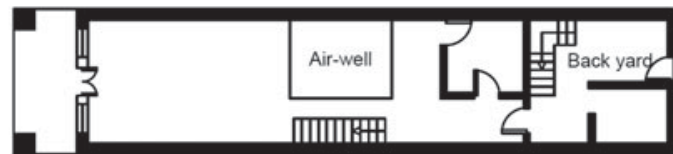

Figure 4. Ground floor layout plan of CSH: (a) CSH in Malacca (adapted from Tan 1988), (b) CSH in Singapore (adapted from Davison and Tettoni 2011), and (c) CSH in Penang (adapted from Omar and Syed-Fadzil 2011).
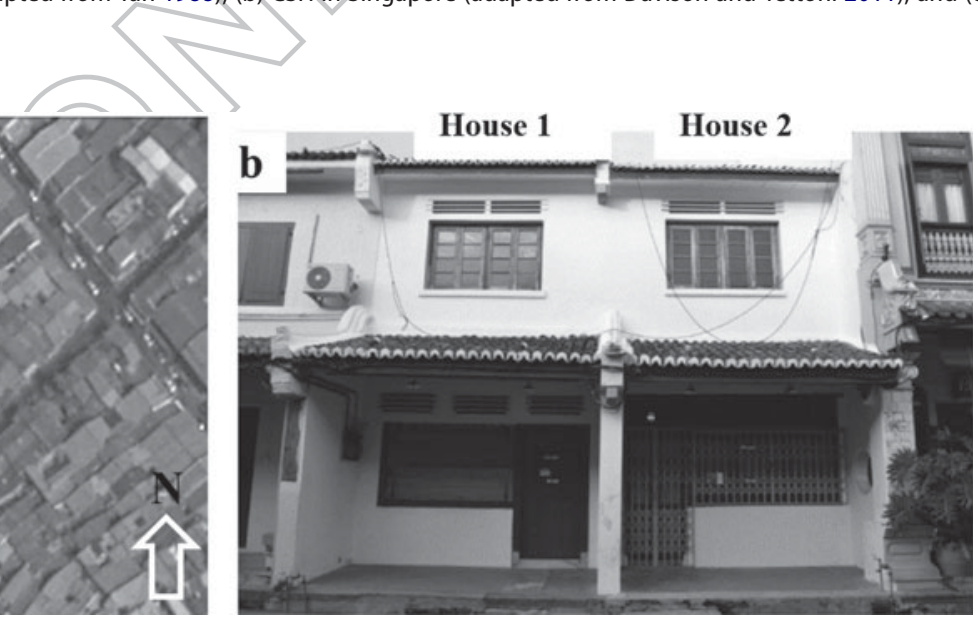

\section{$\mathbf{a}$}

Figure 5. House 1 and 2: (a) Location; (b) front exterior view (Source: Google Earth, imagery dated on 18 January 2015).

planning, form and architectural design are comparable (Tan 1988). The CSH found in Malacca typically has two or more halls with intermediate air-wells and a fenced backyard (Davison and Tettoni 2011). These CSHs' like others found in the old cores of tropical port cities such as Singapore, Penang and Batavia have simple elongated plans, multiple air-wells and narrow corridors (Omar and Syed-Fadzil 2011) (Figure 4).

Two CSHs are selected for this survey; they are located at 54-56 Jalan Tun Tan Cheng Lock in the core of the city. The two houses are adjoined by a party wall (Figure 5). House 1 has two air-well type courtyards and a large backyard. House 2 has one air-well type courtyard and a backyard. The two houses are inter-connected on both levels. The two houses are located in a cluster of $\mathrm{CSHs}$ with similar configuration (Figure 6). It is a densely built up neighbourhood, with a gross building coverage ratio of $76 \%$. There are no high-rise buildings surrounding the site. The prevailing wind is in parallel to the building orientation. Therefore, the influence of the incoming wind from the surrounding environment was considered relatively insignificant. The two shophouses were donated to the Department of Architecture, National University of Singapore to function as a Centre for Asian Architectural and Urban Heritage in Malacca. They have been well preserved to emulate the original spatial planning, form and architectural design of a typical CSH found in most tropical port cities in Southeast Asia.

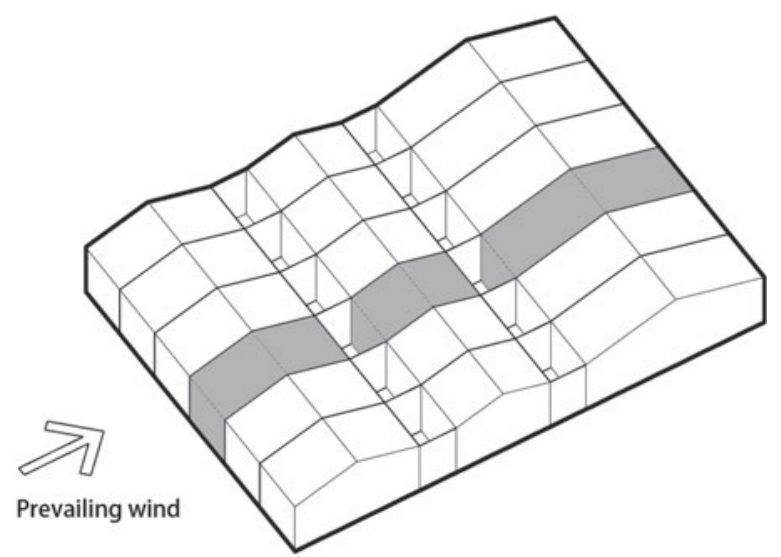

456

Figure 6. Site condition and prevailing wind (drawn by the authors).

\section{Field measurement}

The field measurement was conducted in April 2016. The measured period can be considered as a representative of a fair weather day in Malacca. For the purpose of this study, a fair weather day in a month is used as a representation of average conditions in terms of air temperature in Malacca city. Fair weather days include clear and intermediate sky conditions with 


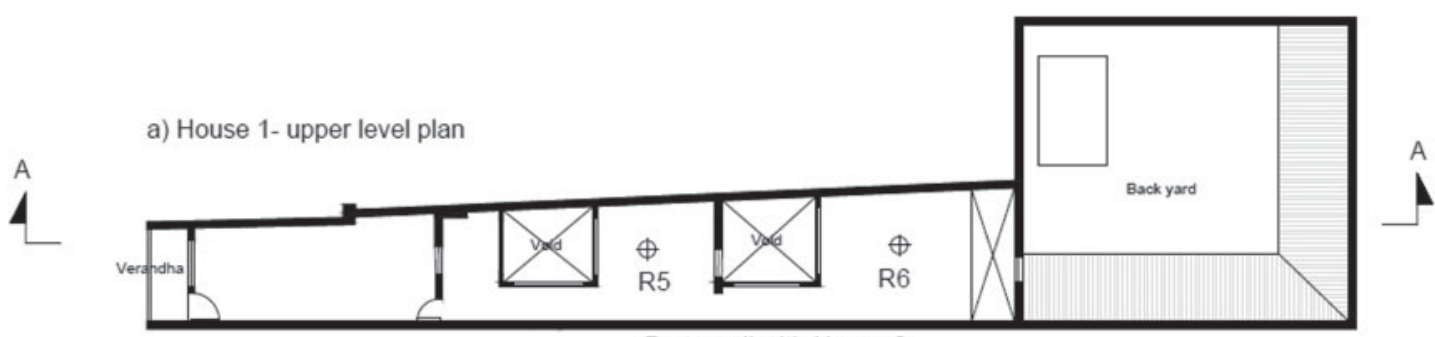

Party wall with House 2
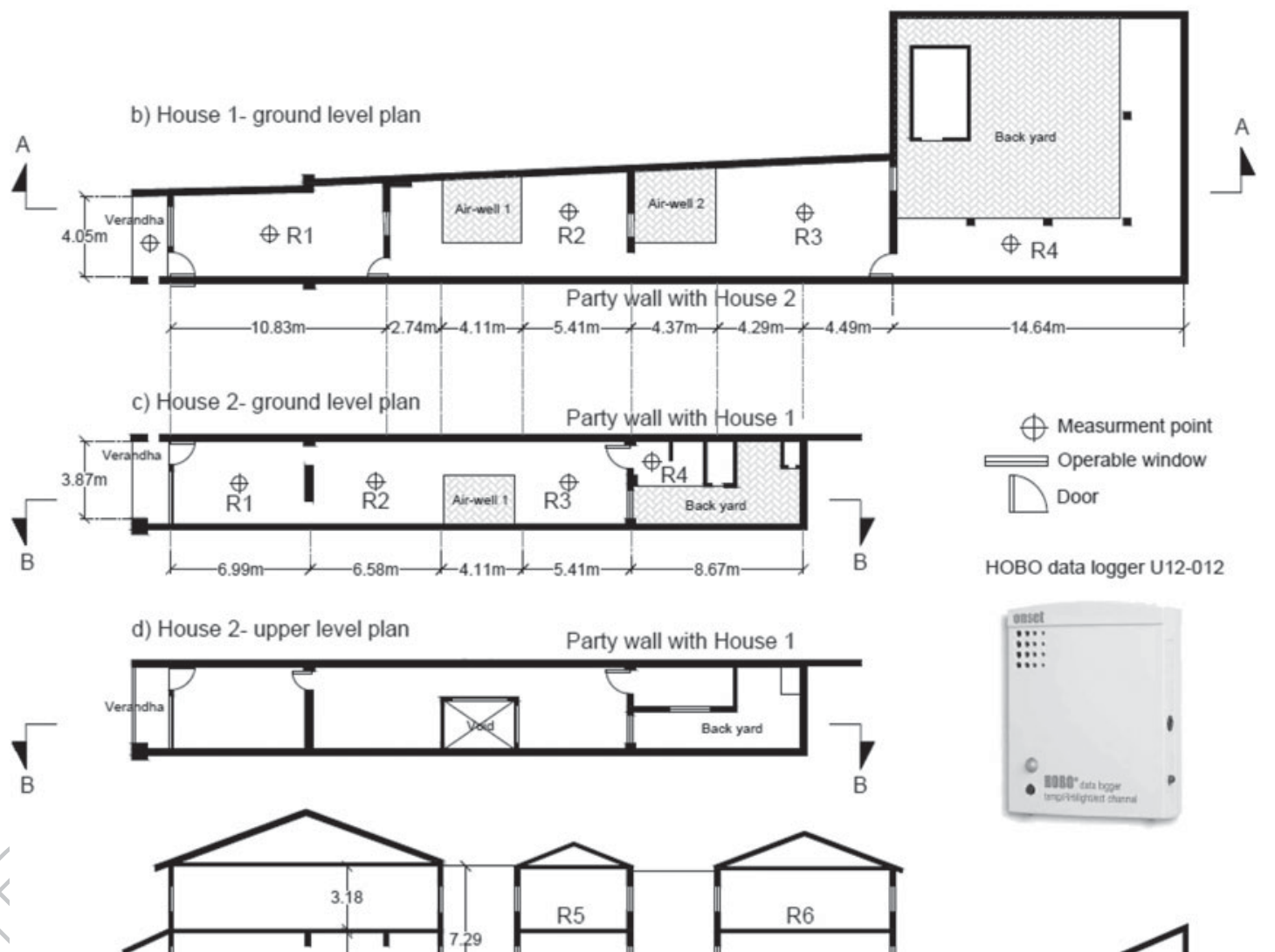

d) House 2- upper level plan
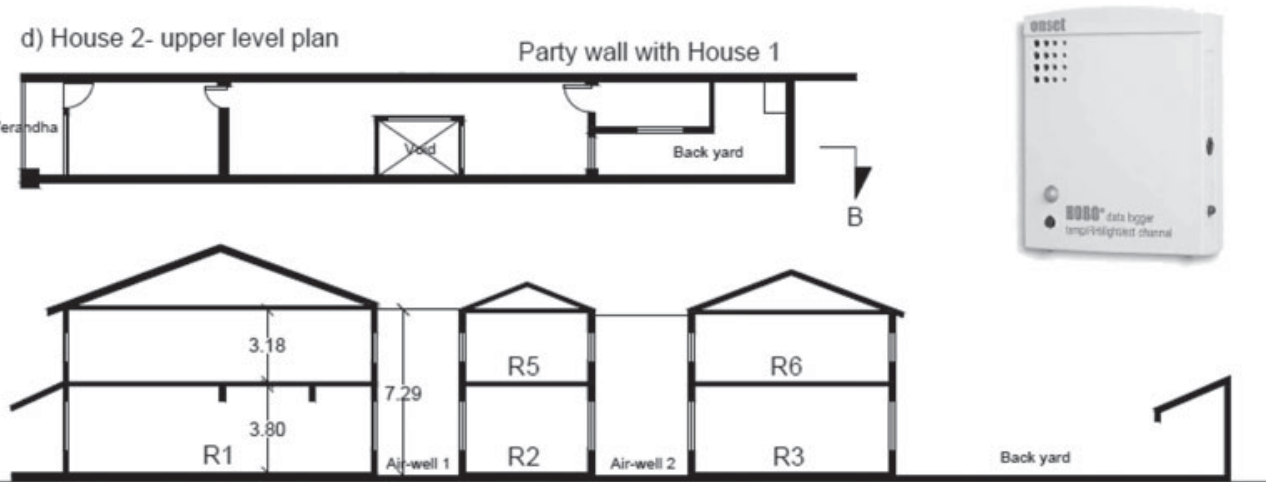

e) Section A-A

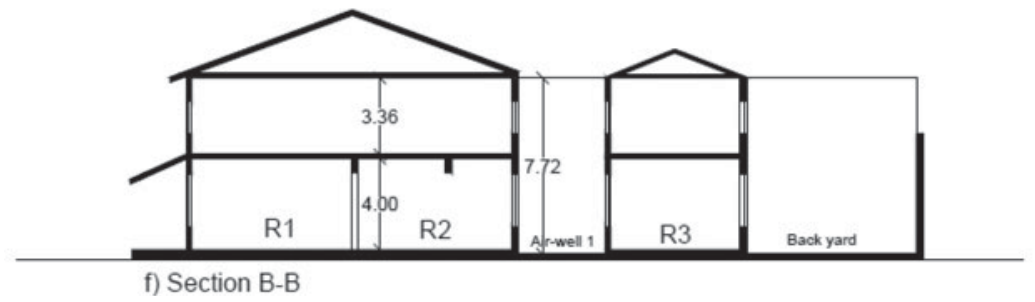

Figure 7. House 1 and 2: layout plans, sections, measurement points and equipment used for measurement.

relatively constant high outdoor air temperatures during the daytime.

The air temperature and relative humidity were measured at nine locations on first floor level and two locations at second floor level in the two houses for 26 consecutive hours in April 2016. The measured locations are indicated in Figure 7. All measurements were taken at $0.4 \mathrm{~m}$ height above floor. Data were logged using HOBO data logger U12-012 at 30 second intervals. The technical specifications of the instruments used for field survey are summarized in Table 1. The instruments have been calibrated and certified by Shanghai Institute of Metrology Technology (SIMT), a Chinese authority certifying meteorological instruments. Positions of doors and windows were kept same throughout the survey. All doors and operable windows of front walls and doors between House 1 R1 and R2 were kept closed during the survey. Description of each courtyard and backyard is summarized in Figure 8 and Table 2. 


\begin{tabular}{lccccc}
\hline Monitored parameters & Instrument name & Measurement range & Accuracy & Resolution & Response time \\
\hline Air temperature & $\mathrm{HOBO}$ U12-012 & $-20-70^{\circ} \mathrm{C}$ & $\pm 0.35^{\circ} \mathrm{C}$ & $0.03^{\circ} \mathrm{C}$ & $6 \mathrm{~min}$ \\
Relative humidity & $\mathrm{HOBO}$ U12-012 & $5-95 \% \mathrm{RH}$ & $\pm 2.5 \% \mathrm{RH}$ & $0.05 \% \mathrm{RH}$ & $1 \mathrm{~min}$ \\
\hline
\end{tabular}

(a)

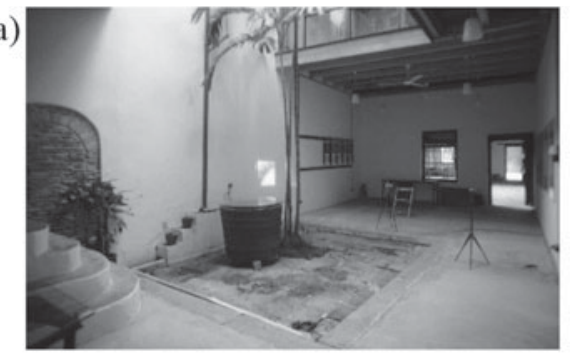

(c)

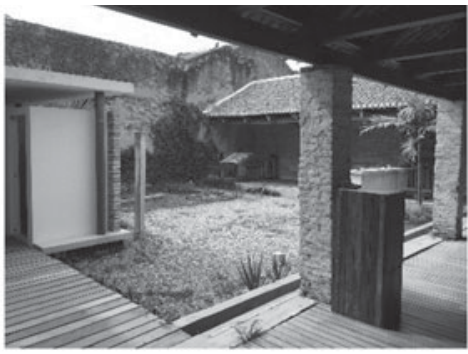

(b)

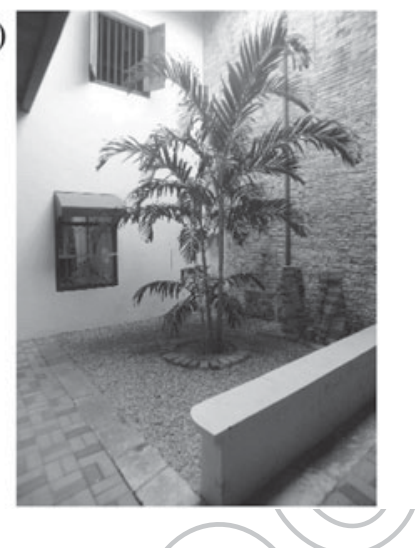

(d)

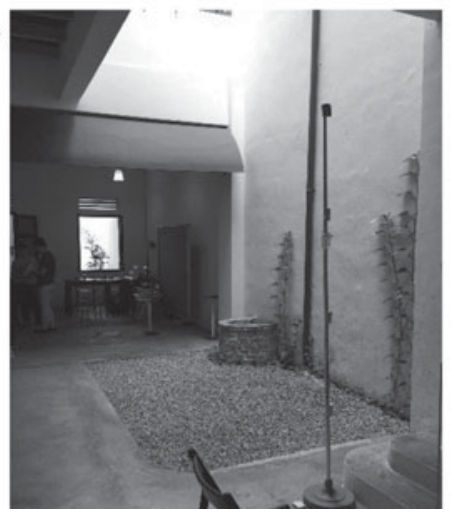

(e)

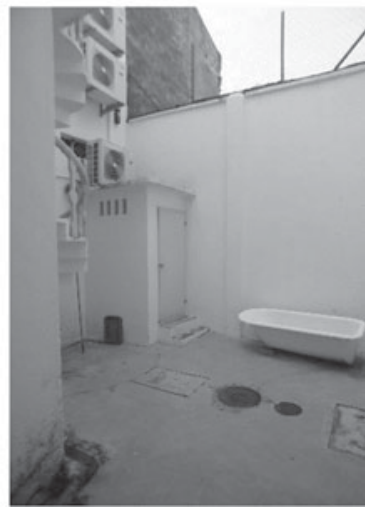

Figure 8. Courtyards and backyards in House 1 and 2: (a) 1-AW1, (b) 1-AW2, (c) 1-BY, (d) 2-AW1, and (e) 2-BY.

Table 2. Description of air-wells and backyards in House 1 and 2.

\begin{tabular}{llccccc}
\hline Location & & Abbreviation & $\begin{array}{c}\text { Width } \\
(\mathrm{m})\end{array}$ & $\begin{array}{c}\text { Length } \\
(\mathrm{m})\end{array}$ & $\begin{array}{c}\text { Height } \\
(\mathrm{m})\end{array}$ & $\begin{array}{c}\text { Height/ } \\
\text { length }\end{array}$ \\
\hline House 1 & Air-well 1 & 1-AW1 & 3.5 & 4.11 & 7.29 & 1.77 \\
& Air-well 2 & 1-AW2 & 3.9 & 4.37 & 7.29 & 1.67 \\
& Backyard & 1-BY & 10.7 & 12 & 2.80 & 0.23 \\
House 2 & Air-well 1 & 2-AW1 & 2.5 & 4.11 & 7.72 & 1.87 \\
& Backyard & 2-BY & 4.5 & 8.9 & 7.72 & 0.87 \\
\hline
\end{tabular}

\section{Airflow simulation}

641 The buildings are oriented in parallel to the predominant wind direction of Malacca which is southwest and northeast. In this research 2D modelling was selected. Prevailing wind parallel to the buildings in southwest and northeast direction across section $A-A$ and $B-B$ are used to quantify the mechanisms of air exchange. Three different scenarios in each building were investigates: the doors and operable windows on the front and rear walls opened (V1), the doors and operable windows on the front walls closed and the rear opened (V2), the doors and operable windows on the front and rear walls closed (V3).

The air velocity and normalized mean age, as two important natural ventilation performance indicators are used to quantify the freshness of the air of the particular space. Normalized mean age of air is used to explain the air change efficiency of a space. Age of air measures how old the air is in a space. The values for mean age of air are adjusted to a notionally common scale. The CFD simulation was conducted using Fluent with mesh size down to $0.15 \mathrm{~m}$ for all the building boundaries including walls, floors, and roofs to capture the smallest detail of windows and eaves. A coarser mesh is used in areas far from the building boundaries, with a growth rate of 1.05 . The building has a complex geometry therefore a hybrid mesh is used. A structured mesh is used for the rectangular space in the indoor areas and courtyards. A quad-dominant mesh is used for the outside areas with an irregular shape (Figure 9). In Section A-A (House 1) for scenario V1, V2 and V3, the mesh size is 50K. In Section B-B (House 2) for scenario V1, V2 and V3, the mesh size is 36K.

The height of the tallest building is $\mathrm{H}$; distance from the inlet to the building is $8 \mathrm{H}$; distance from the outlet to the building is $20 \mathrm{H}$; domain height is $10 \mathrm{H}$. A constant incoming wind velocity of $4 \mathrm{~m} / \mathrm{s}$ which equals to the average velocity for April in Malacca from the weather database is applied to all scenarios. Zero normal gradient is applied to outlet while no-slip wall boundary with standard wall function is applied to roof, floor and wall. The realizable $\mathrm{k}-\varepsilon$ model which is one of the most widely acceptable turbulence models is used. A user-defined source is released in all the rooms with a time-average rate $\left(S_{C}\right)$ to calculate the age of air. The age of air can be calculated by the concentration of the source (c): $c / S_{c}$. The standard scheme is used for the pressure and velocity coupling. All transport equations were discretized by the second-order upwind scheme. The simulation was conducted for 10,000 iterations till all residuals become constant (Figure 10). The residuals are $1 \mathrm{e}-05$ for continuity, $1 \mathrm{e}-07$ for epsilon, $k$ and all velocity component and $1 \mathrm{e}-08$ for user defined age of air.

The wind tunnel experiment carried out by Karava (2008) was used for cross comparison with the CFD simulation to check the validity of the simulation tool. The experiment building 


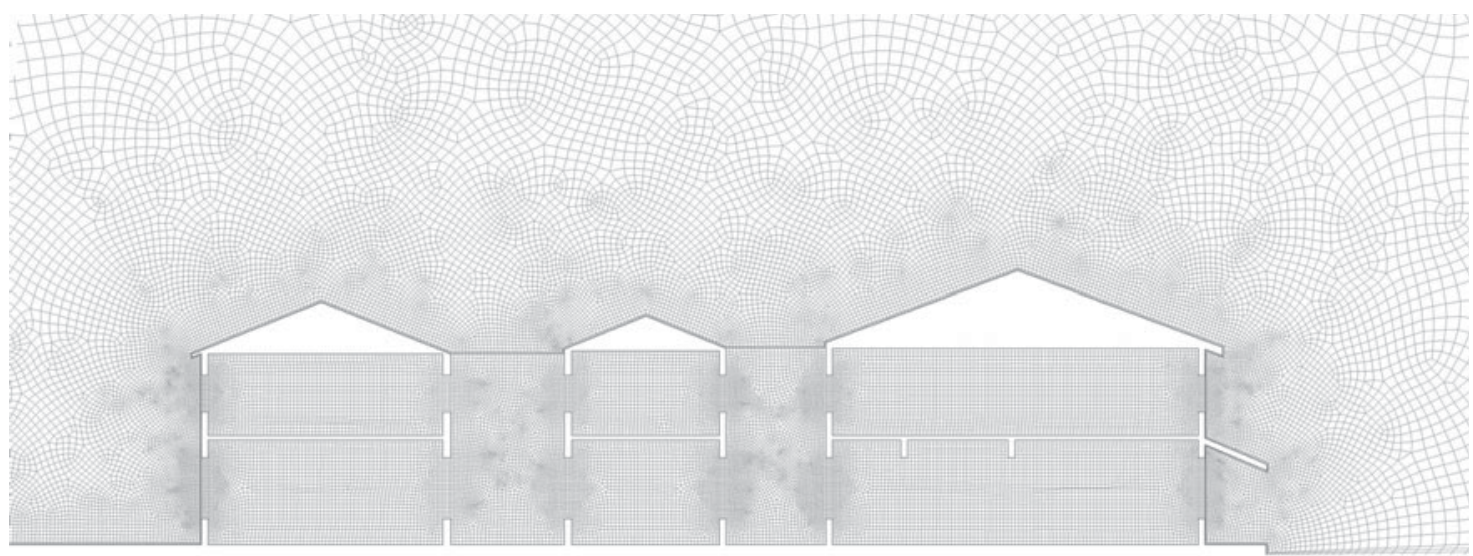

Figure 9. Computational mesh for Section A-A (House 1).

model was a $100 \times 100 \times 80 \mathrm{~mm}$ box corresponding to a building of $20 \times 20 \times 16 \mathrm{~m}$. The computational domain was built with $11 \mathrm{H}(9 \mathrm{~m})$ in the lateral direction, $6 \mathrm{H}(4.8 \mathrm{~m})$ tall in the vertical direction and $21 \mathrm{H}(17 \mathrm{~m})$ in the stream-wise direction. The tested building was placed $5 \mathrm{H}$ to the inlet and $15 \mathrm{H}$ to the outlet. Figure 11 shows the dimension of building that are tested in wind tunnel and modelled in the computation domain.

The inlet boundary conditions for the simulation were based on PIV measurement. An incoming wind velocity of $6.6 \mathrm{~m} / \mathrm{s}$ at a reference height of $0.8 \mathrm{~m}$ (building height) with a power-law exponent equal to 0.11 was applied. No-slip wall boundary conditions were used for building surface, and ground, top and lateral boundaries of the domain. The pressure outlet boundary condition was used with zero static pressure. As the building wall was modelled with a thickness of $2 \mathrm{~mm}$, a minimum mesh length of $1 \mathrm{~mm}$ mesh size was used to capture the details of the building. The expansion ratio of 1.3 was applied between two consecutive grids to get a smaller mesh while satisfying the suggestion in CFD practice guidelines. Figure 12 shows the comparison of wind velocity ratio and velocity vector field between PIV measurement and CFD simulation. It is clear that there is good agreement between the result from CFD simulation and PIV measurement.
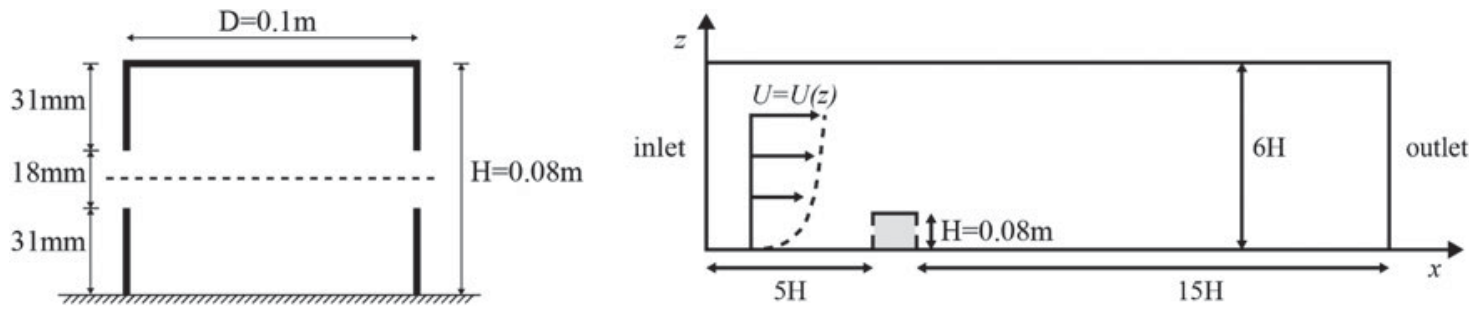

Figure 11. Schematic drawing of the tested building in the wind tunnel and computation domain. 
841

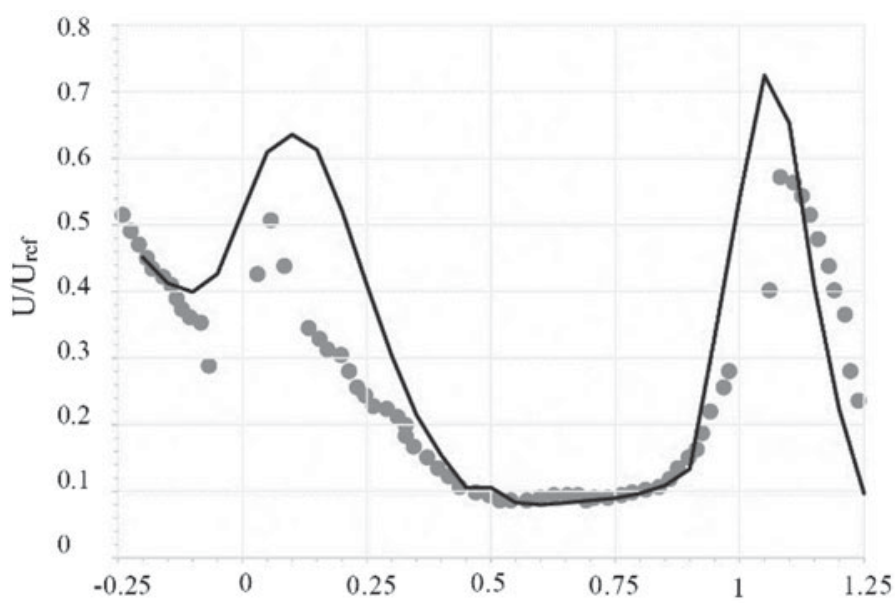

$\bullet \bullet \quad$ PIV result

901

$-\quad$ CFD simulation

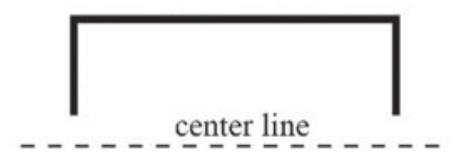

911

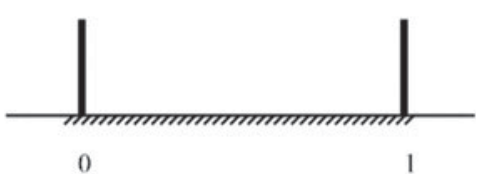

0

916

Figure 12. Wind velocity ratio along the centre line throughout the indoor area.

\section{Results}

\section{Field measurement}

Figures 13 and 14 show temporal variations of measured air temperature at different locations with the corresponding outdoor weather conditions. For all measured locations, maximum air temperature is reported between $16: 30$ and 17:00 $\mathrm{h}$ and minimum air temperature is reported between 5:30 and 7:00 $\mathrm{h}$. Among the measured locations, the highest day time air temperature is found in House1-R4 which was located next to a
Indoor air temperature House 1

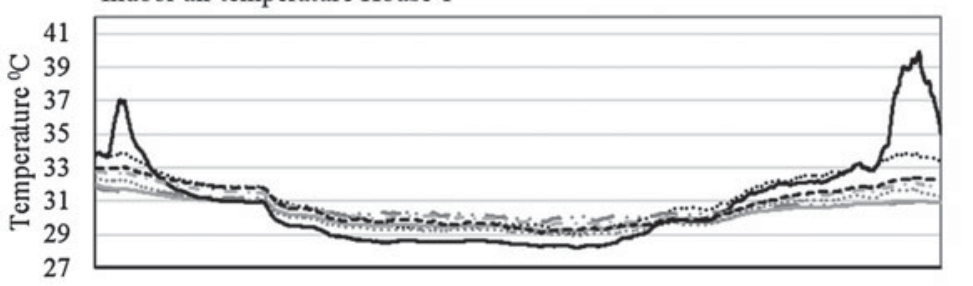

......... Verandah

$-\cdots \mathrm{R} 1$

$-\mathrm{R} 2$

…… R3

$-\mathrm{R} 4$

$-\cdot$ R5

$----R 6$

931

Indoor air temperature House 2

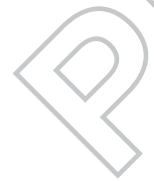

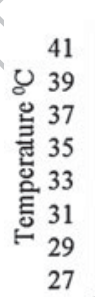

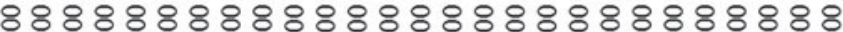

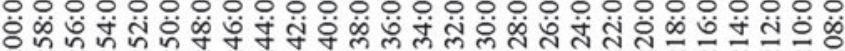

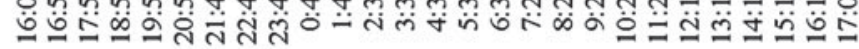

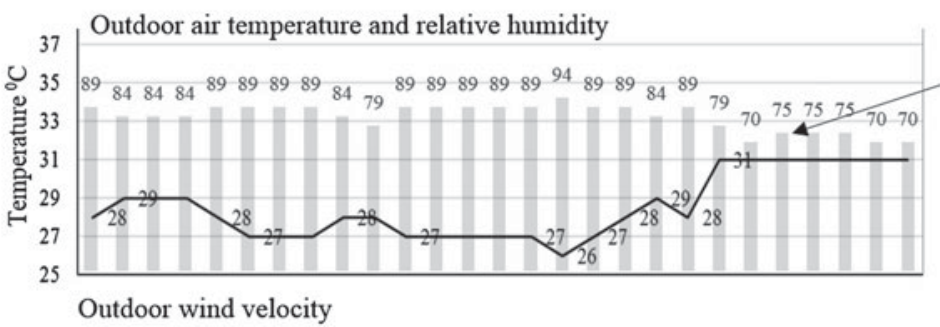

Relative humidity

$$
\begin{aligned}
& \text {-...... Verandah } \\
& ---- \text { R1 } \\
& ---- \text { R2 } \\
& -\cdot-\text { R3 } \\
& - \text { R4 }
\end{aligned}
$$

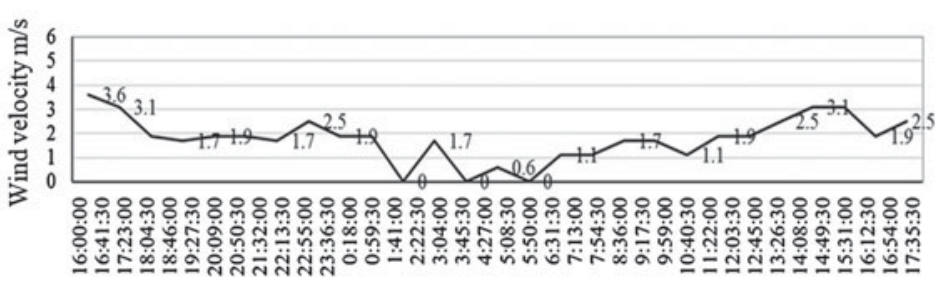

Figure 13. Temporal variations of measured air temperature and corresponding outdoor weather conditions. 

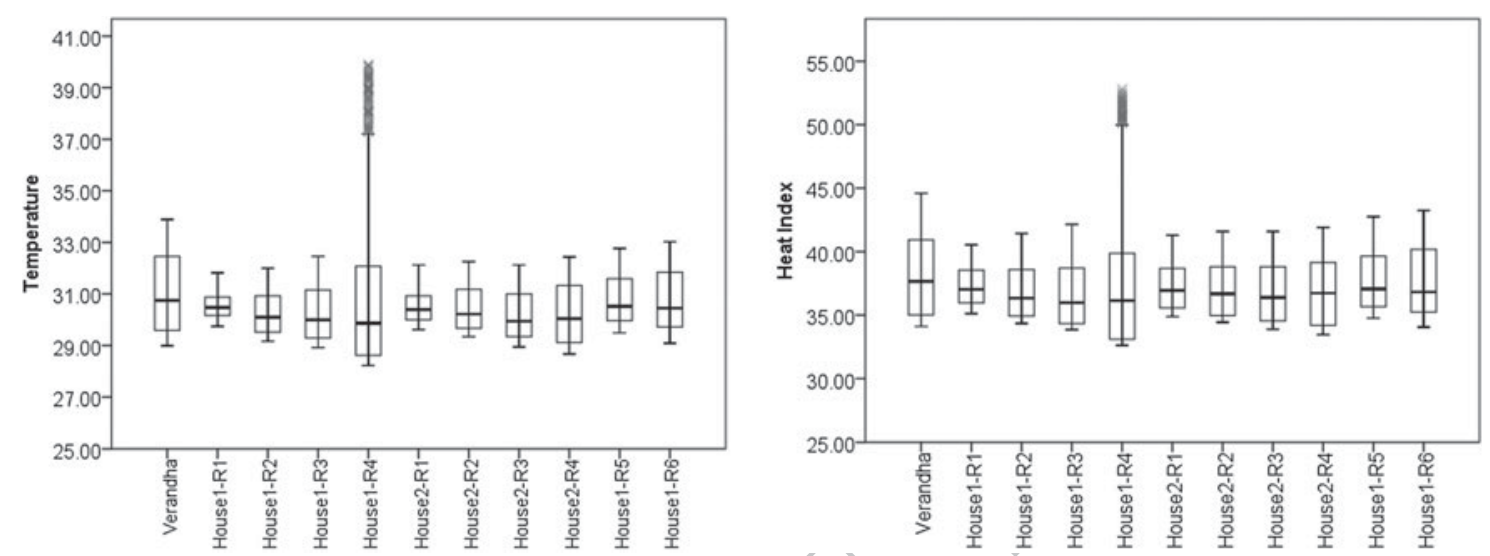

1021

Figure 14. Statistical summary of measured air temperature and $\mathrm{HI}$ in degree Celsius.

large backyard (1-BY). The maximum day time air temperature in House1-R4 exceeded that of the verandah by a considerable value of 6.9 degree Celsius. The lowest day time peak air temperature and highest night-time air temperature is found in rooms located at the front of the two houses (House 1-R1 and House 2-R1). These rooms had the least contact with the external environment as the front doors and windows closed during the filed survey. The rooms located between air-well courtyards and backyards at ground floor level had lower night-time air temperature by approximately $0.5-0.9{ }^{\circ} \mathrm{C}$ than those located at the front of the two houses. Rooms located between air-well courtyards and backyards also had lower heat gain during daytime which only resulted in a $0.2-0.6^{\circ} \mathrm{C}$ increase in daytime peak air temperature compared to the rooms located at the front of the two houses. Heat gains from the roof resulted in higher maximum daytime air temperatures in rooms on upper floor level than those at the ground level.

Heat Index (HI) is an index that combines air temperature and relative humidity, in shaded areas, as an attempt to determine how hot it would feel if the humidity was some other value in the shade. The calculation of $\mathrm{HI}$ used the equation proposed by Steadman (1979). Statistical significant difference of measured mean air temperature and $\mathrm{HI}$ between the different locations is explored using statistical analysis software IBM SPSS statistics provided by the National University of Singapore. One-way ANOVA and its non-parametric counterpart Welch ANOVA was used to explore significant difference in means for air temperature and $\mathrm{HI}$ of the different locations. The assumption of homogeneity of variances was assessed by Levene's test for equality of variances. The Levene's test was statistically significant. Therefore, equal variance is not assumed and the results are interpreted using Welch ANOVA and Games-Howell post hoc test.

Table 3 summarizes the result of One-way ANOVA and Welch ANOVA tests that investigate the statistically significant difference of means. The measured mean air temperature and $\mathrm{HI}$ were statistically significantly different between measured locations. Figure 15 shows the means plot for air temperature and $\mathrm{HI}$ at the different rooms of House 1 and 2. In both houses, the rooms on ground floor level located between air-well courtyards and backyards (House 1-R2, R3, House 2-R3, and R4) have significantly lower mean air temperature and $\mathrm{HI}$ than other measured locations. Verandah has significantly higher mean air temperature and $\mathrm{HI}$ than all other measured locations. The highest mean difference in air temperature is found between Verandah and House 2-R3 (0.95, 95\% Cl [0.85-1.05], $p=.0005)$. The highest mean difference in $\mathrm{HI}$ is found between Verandah and House $1-\mathrm{R3}(1.59,95 \% \mathrm{Cl}[1.36-1.81], p=.0005)$.

Table 4 summarizes the result for Spearman's rank-order correlation between indoor air velocity and indoor air temperature and $\mathrm{HI}$ for the whole day and between 20:00 and 9:00 $\mathrm{h}$. During this period of time, when the outdoor air temperature is expected to be relatively low, temperature and $\mathrm{HI}$ show a statistically significant medium and negative association with indoor air velocity. It indicates lower indoor air temperature and $\mathrm{HI}$ at higher indoor air velocities.

\section{Airflow simulation}

Figure 16 shows the normalized mean age of air in different rooms of House 1 and 2 based on the three scenarios. Table 5 summarizes the means and standard deviations for normalized age of air and air velocity for the measured rooms under the three different scenarios in House 1 and 2. The normalized mean age of air and air velocity was analysed for 0.4 and 1.2 mheights from the finished floor level (FFL) for each room. Statistical significant difference of means for normalized age of air and air velocity in various rooms was explored using One-way ANOVA and its non-parametric counterpart Welch ANOVA. The Levene's

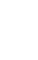

\section{6}

Table 3. Results of one-way ANOVA for air temperature and $\mathrm{HI}$ for measured locations.

\begin{tabular}{|c|c|c|c|c|c|c|c|c|}
\hline & \multicolumn{2}{|c|}{$\begin{array}{l}\text { Levene's test for } \\
\text { equality of variances }\end{array}$} & \multicolumn{3}{|c|}{ ANOVA } & \multicolumn{3}{|c|}{$\begin{array}{l}\text { Robust tests of equality of } \\
\text { means }\end{array}$} \\
\hline & $F$ & Sig. & $F$ & $\begin{array}{l}\text { df (within } \\
\text { groups) }\end{array}$ & $\begin{array}{l}\text { Sig. (between } \\
\text { groups) }\end{array}$ & $F$ & $\begin{array}{l}\text { df (within } \\
\text { groups) }\end{array}$ & $\begin{array}{l}\text { Sig. (between } \\
\text { groups) }\end{array}$ \\
\hline Temperature & 1595.4 & .000 & 189.38 & 34319 & .000 & 214.9 & 13655.56 & .000 \\
\hline $\mathrm{HI}$ & 1134.4 & .000 & 120.90 & 34319 & .000 & 119.4 & 13683.34 & .000 \\
\hline
\end{tabular}


1081

1086

1091

1096

1101

1106

1111

1116

1121

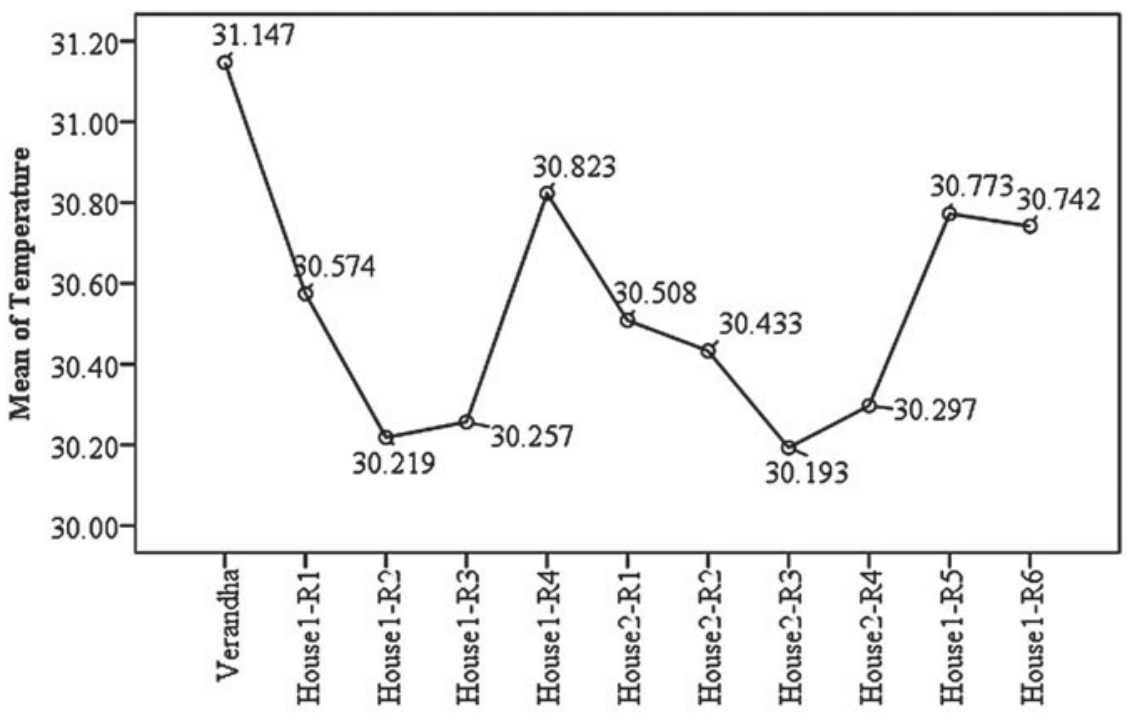

1141

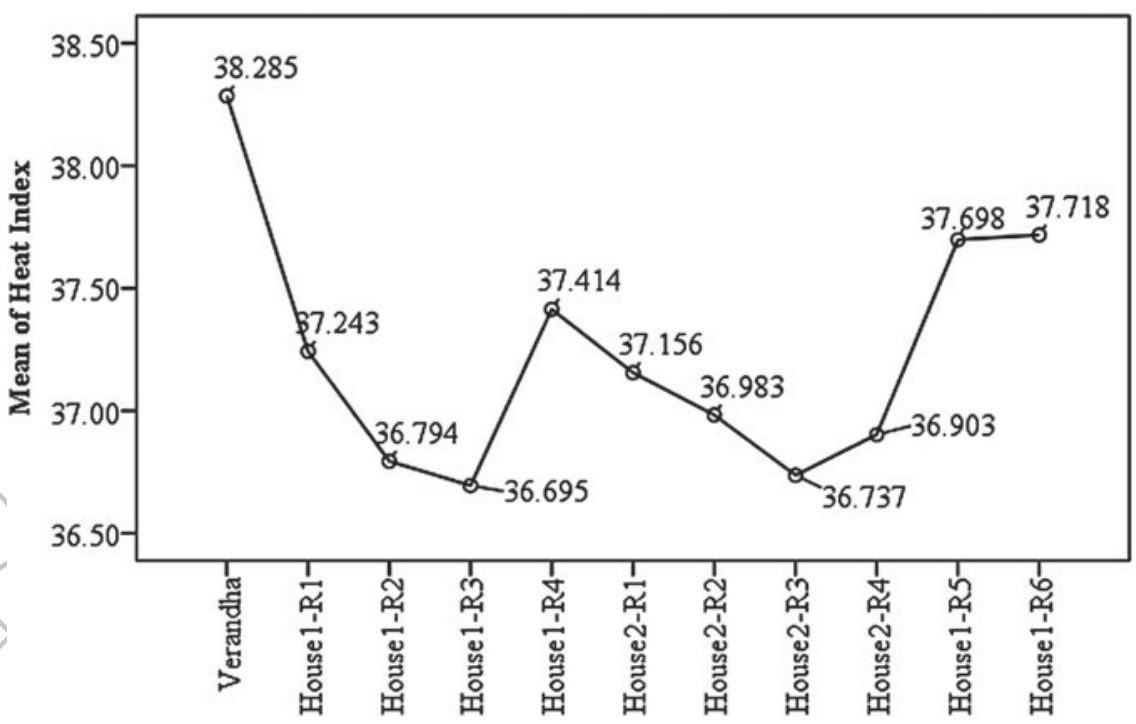

1161

1166

1171

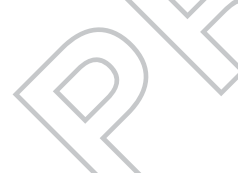

Figure 15. Means plot for air temperature and $\mathrm{HI}$ (degree Celsius).

Table 4. Result of Spearman's rank-order correlation for indoor air velocity against indoor air temperature and $\mathrm{HI}$.

\begin{tabular}{lcccc}
\hline & Duration & & Temperature & HI \\
\hline Velocity & Whole day & rs & $-.185^{* *}$ & $-.144^{* *}$ \\
& & $n$ & 24968 & 24968 \\
& $20: 00-9: 00 \mathrm{~h}$ & $r s$ & $-.406^{* *}$ & $-.381^{* *}$ \\
& $n$ & 12483 & 12483 \\
\hline
\end{tabular}

**Correlation is significant at the 0.01 level (2-tailed). correlation coefficient ( $r s)$, number $(n)$.

test was statistically significant. Therefore, equal variance is not assumed and the results are interpreted using Welch ANOVA and followed up with Games-Howell post hoc analysis.

Table 6 summarizes the result of One-way ANOVA and Welch ANOVA. Normalized mean age of air and air velocity was statistically significantly different between the measured locations in both houses. Figures 17 and 18 show the means plot for normalized mean age of air and air velocity in the different rooms for the three different scenarios. The rooms which could not maintain cross ventilation when the doors and operable windows of the front and rear walls were closed (scenario V2 and V3) resulted in an enormous increase in the mean value for normalized age of air. In House 1 during scenario V2, the mean value of normalized age of air in R1 was statistically significantly higher than all other rooms in the house. The highest mean difference is between R1 and R3 (3879.5, 95\% Cl [443.4-7315.5], $p=.02$ ). In House 2 during scenario V2 the normalized mean age of air in R1 was statistically significantly higher than all other rooms. The highest mean difference is between R1 and R3 $(14135,95 \% \mathrm{Cl}$ [6650-21719], $p=.001$ ). In House 1, during scenario V3, spaces located between air-well courtyards such as R2 and R5 had significantly lower mean for normalized age of air than all other spaces in the house. The highest mean difference is between R3 and R5 (2182.3, 95\% Cl [738.9-3625.6], $p=.002)$. In House 1 when the scenario changed from V2 to V 3 a statistically significant decrease in mean of normalized age of air in R5 of 27.08 ( $F$ $[1,18]=11.24 p=.004)$ can be seen at 1.2 from FFL.

Air speeds greater than $0.2 \mathrm{~m} / \mathrm{s}$ can be used to increase the upper temperature limit of the comfort zone (ASHRAE 2013). The rooms which did not received cross ventilation when the doors and operable windows of the front and rear walls were closed (scenario V2 and V3) resulted in still air conditions $(<0.2 \mathrm{~m} / \mathrm{s})$. 


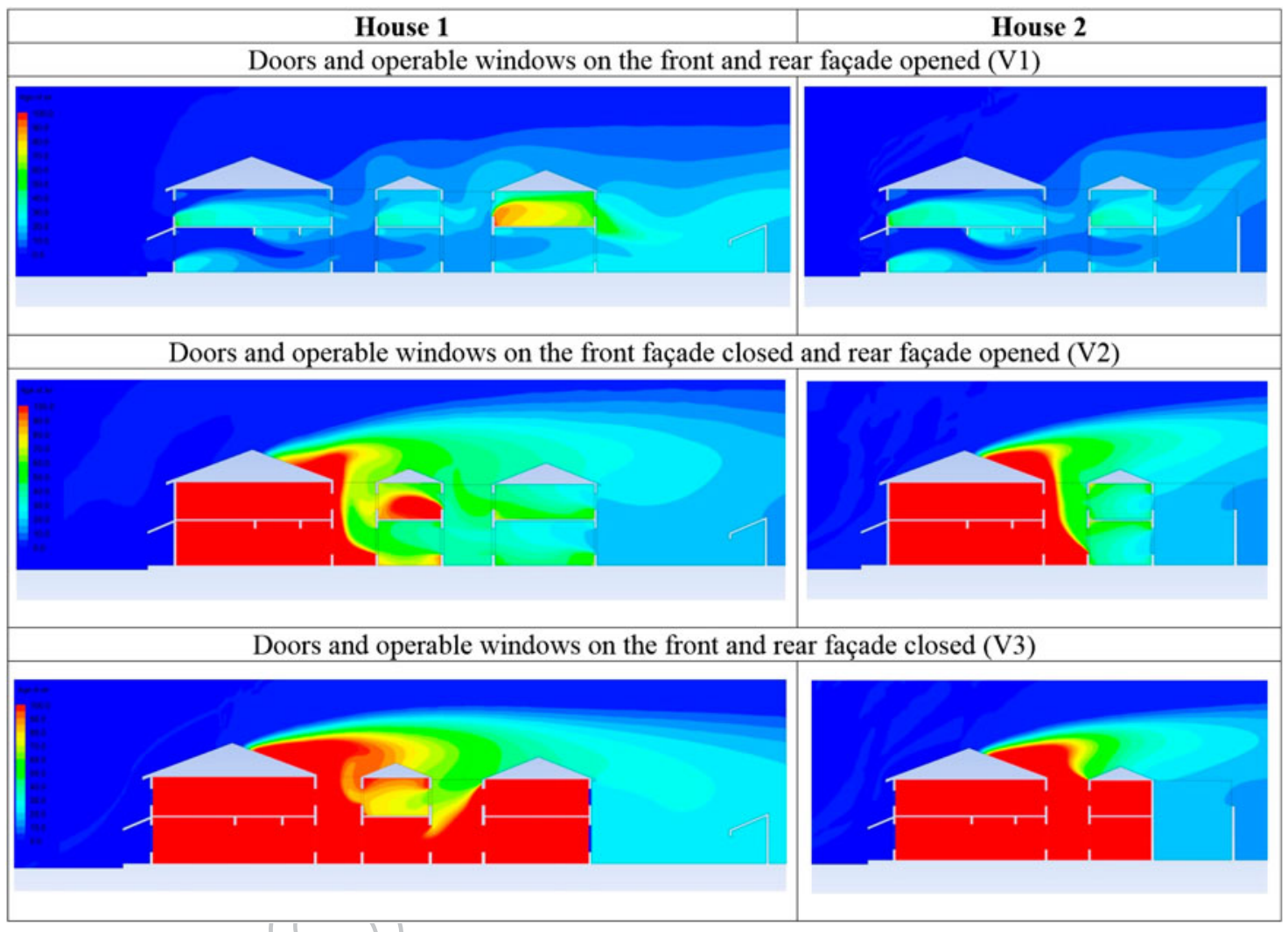

Figure 16. Normalized mean age of air in different rooms of House 1 and 2 during the three tested scenarios.

Table 5. Descriptive analyses of normalized age of air and air velocity.

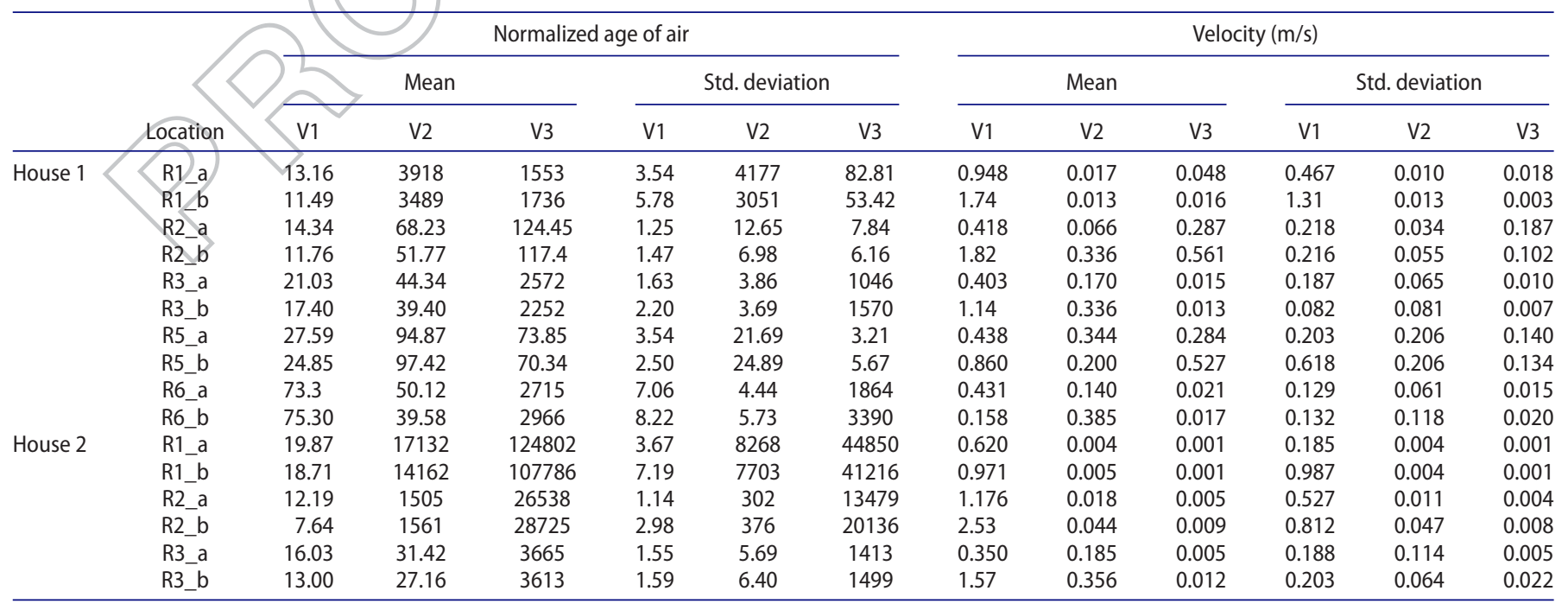

Note: $\mathrm{a}=0.4-\mathrm{m}$ height from $\mathrm{FFL}, \mathrm{b}=1.2-\mathrm{m}$ height from FFL.

In House 1 during scenario V2, the mean value for air velocity in R1 was statistically significantly lower than all other rooms. The highest mean difference is between $\mathrm{R} 6$ and $\mathrm{R} 1(0.73,95 \% \mathrm{Cl}$ $[0.26-0.48], p=.0005)$. In House 2 during scenario V2, the mean value of air velocity in $\mathrm{R} 1$ was statistically significantly lower than all other rooms. In House 1 during scenario V3, spaces located between air-well courtyards such as R2 and R5 had significantly higher mean air velocities than all other spaces. The highest mean difference is between $\mathrm{R} 2$ and $\mathrm{R} 3(0.55,95 \% \mathrm{Cl}[0.41-0.68]$, $p=.0005)$. In House 1, when the condition changed from V2 to $\mathrm{V} 3$ a statistically significant increase in mean air velocity in
$\mathrm{R} 2$ of $0.22 \mathrm{~m} / \mathrm{s}(F[1,18]=37.09, p=.0005)$ and a statistically significant increase in mean air velocity in $\mathrm{R} 5$ of $0.34 \mathrm{~m} / \mathrm{s}(F[1$, 21] $=20.10, p=.0005$ ) can be seen at $1.2 \mathrm{~m}$ from FFL.

\section{Discussion}

This study provides evidence for the potential of cross ventilation of intermediate spaces through the air-well in the Chinse Shophouse. The complexity of natural ventilation, the influence of various design parameters makes it difficult to achieve proper conclusions based on a single research method: either field

1291

\section{6}

1276

1286 
Table 6. Results of One-way ANOVA for normalized mean age of air and air velocity.

1381

\begin{tabular}{|c|c|c|c|c|c|c|c|c|c|c|}
\hline \multirow[b]{2}{*}{$\begin{array}{l}\text { Measured } \\
\text { parameter }\end{array}$} & \multirow[b]{2}{*}{ Location } & \multirow[b]{2}{*}{ Condition } & \multicolumn{2}{|c|}{$\begin{array}{l}\text { Levene's test for } \\
\text { equality of Variances }\end{array}$} & \multicolumn{3}{|c|}{ ANOVA } & \multicolumn{3}{|c|}{$\begin{array}{l}\text { Robust tests of equality of } \\
\text { means }\end{array}$} \\
\hline & & & $F$ & Sig. & $F$ & df (within groups) & $\begin{array}{l}\text { Sig. (between } \\
\text { groups) }\end{array}$ & $F$ & df (within groups) & $\begin{array}{l}\text { Sig. (between } \\
\text { groups) }\end{array}$ \\
\hline \multirow[t]{4}{*}{ Age of air } & House 1 & V1 & 10.50 & .000 & 426.82 & 132 & .000 & 229.39 & 49.99 & .000 \\
\hline & & V2 & 8.42 & .000 & 11.33 & 132 & .000 & 25.29 & 47.31 & .000 \\
\hline & & V3 & 26.50 & .000 & 8.55 & 132 & .000 & 2505.7 & 51.29 & .000 \\
\hline & House 2 & V1 & 13.15 & .000 & 17.49 & 62 & .000 & 23.92 & 27.98 & .000 \\
\hline \multirow[t]{6}{*}{ Velocity } & House 1 & V1 & 42.82 & .000 & 15.57 & 132 & .000 & 113.91 & 47.45 & .000 \\
\hline & & V2 & 5.65 & .000 & 32.54 & 132 & .000 & 88.17 & 45.12 & .000 \\
\hline & & V3 & 31.55 & .000 & 97.07 & 132 & .000 & 53.58 & 44.80 & .000 \\
\hline & House 2 & V1 & 9.21 & .000 & 19.34 & 62 & .000 & 49.62 & 28.35 & .000 \\
\hline & & V2 & 24.73 & .000 & 72.26 & 62 & .000 & 63.07 & 26.36 & .000 \\
\hline & & V3 & 3.63 & .006 & 2.34 & & .052 & 5.90 & 26.23 & .001 \\
\hline
\end{tabular}

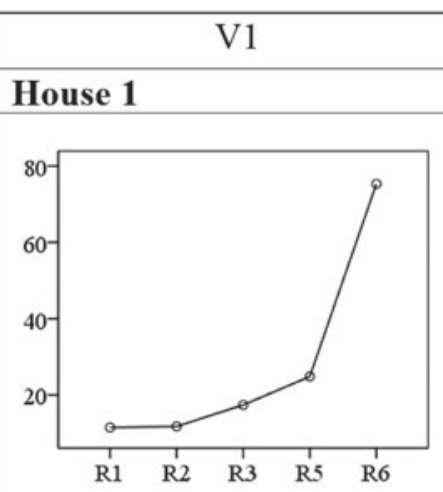

\section{House 2}
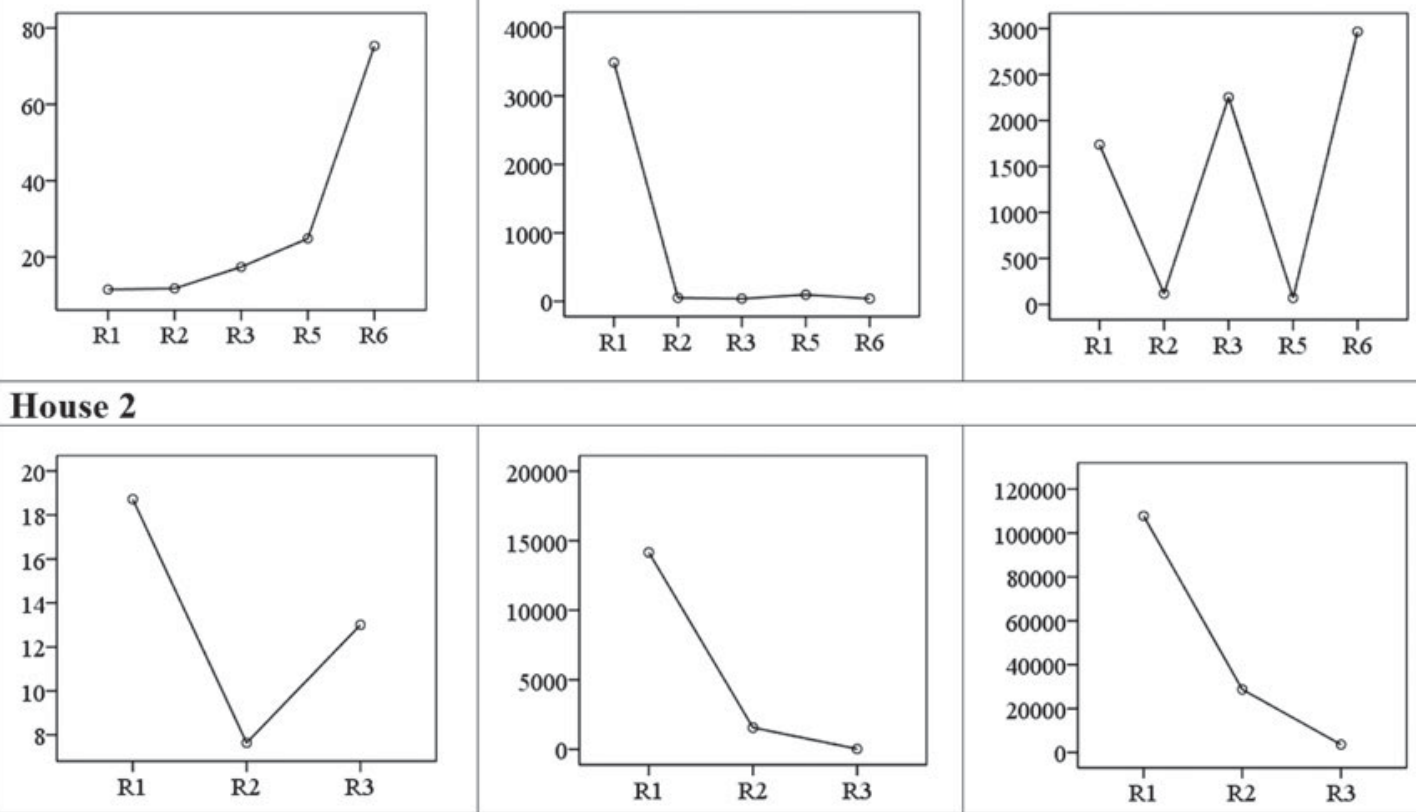

1401

1391

1406

Figure 17. Means plot for normalized mean age of air in rooms of House 1 and 2 at $1.2 \mathrm{~m}$ height from FFL.

measurement or computer simulation. Therefore, the research conducted both field measurement and computer simulation, aiming to take advantage of the two methods to critically disclose the environmental performance of the air-well type tropical shophouse. Combining the two methods, the present study reveals two important findings.

First, the most desirable thermal environment inside the house is found in spaces located near the air-well courtyards. In both surveyed CSHs spaces which were located between air-well courtyards and backyards had significantly lower air temperature and $\mathrm{HI}$. Although larger backyards facilitated lower air temperatures in adjacent semi-open spaces at night, these spaces had very high air temperatures during daytime peak hours. The rooms located near air-well courtyards on the ground floor level had better overall day and night-time thermal environments compared to all other spaces in the houses. Higher shading which is characteristic of the air-well courtyard reduced overheating of the scant interior in the CSH during daytime peak hours.

Second, when the prevailing wind flows in parallel to the longer axis of the building better air circulation and indoor air velocity can be maintained in intermediate spaces of the $\mathrm{CSH}$ through cross ventilation using several air-well courtyards. Single-sided ventilation from air-well courtyards was not effective to significantly reduce the normalized age of air of intermediate spaces. Lack of cross ventilation resulted in still air in the rooms. A significant increase in air velocity of $0.2 \mathrm{~m} / \mathrm{s}$ was observed in spaces between air-well courtyards (House 1-R2, R5) when the building was only ventilated from the air-well (V3) as opposed to supplemented ventilation from rear openings (V2). This is also reflected by a reduction of normalized mean age of air when the tested scenario changed from V2 to V3; however, reduction in 


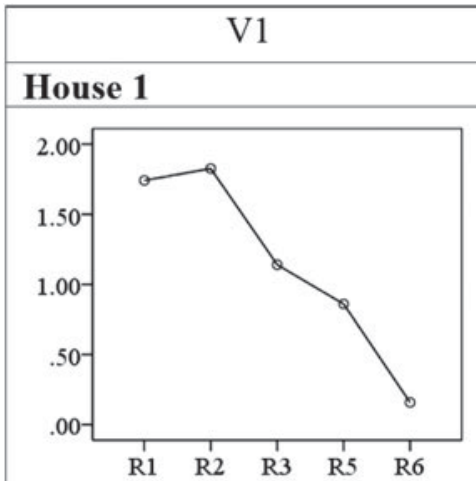

V2

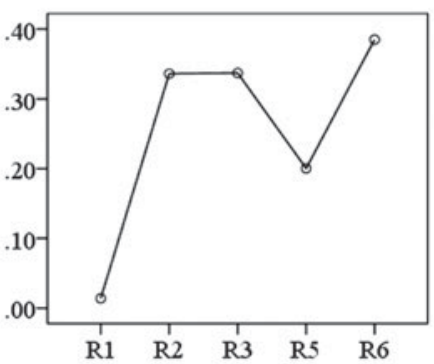

House 2
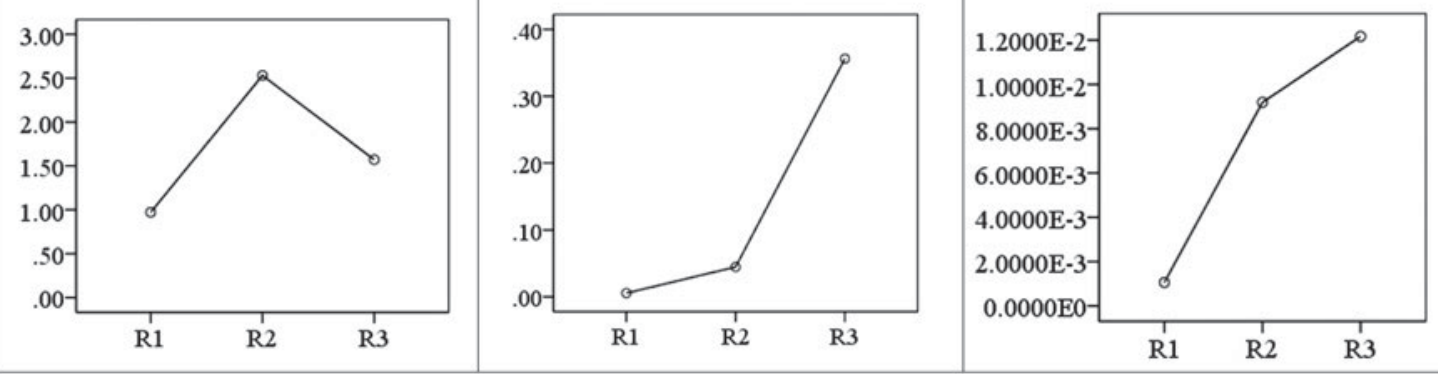

Figure 18. Means plot for air velocity in rooms of House 1 and 2 at $1.2 \mathrm{~m}$ height from FFL.

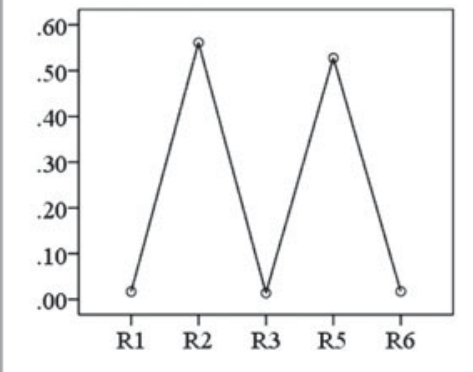

1501

1506

1511

1516

1521

1526

normalized mean age of air is only seen in the upper floor room (House 1-R5).

The findings from the field measurement echo pervious research that spaces adjacent to air-wells had better thermal environments than other spaces in a CSH (Kubota et al. 2017; Toe and Kubota 2015). Toe and Kubota (2015) compared the thermal environment of the same type of CSHs studied in the present research with those traditional Malay houses under open window conditions. The thermal environment of the CSH is best under night ventilation condition; spaces located near air-wells in CSH had better thermal environments than traditional Malay house under daytime ventilation condition. The temperature in spaces near air-wells in the CSH was lower than that in immediate outdoors by up to $5-6^{\circ} \mathrm{C}$; while in the traditional Malaya house the indoor air temperatures was higher than the outdoors by around $1{ }^{\circ} \mathrm{C}$ during the daytime peak hours. Kubota et al. (2017) found that the design characteristics of air-wells had a significant influence on the daytime thermal environment of the CSH and did not significantly influence the night-time thermal environment. CSH which only had deep/closed type of air-wells (such as those found in the CSH used for this survey) had better thermal environments than those which had a combination of deep/closed type and small/staggered type. The small/staggered type increased ventilation during daytime which resulted in more heat gain.

Use of naturally ventilated atria to improve the indoor thermal environment is influenced by the design approach such as atrium components, configurations and ventilation technique. External variables (Temperature, solar radiation, wind) and internal variables (internal heat load, expected comfort level) modify the influence of the design approach (Moosavi et al. 2014). Ideally tropical climates benefit from night cooling, taking the advantage of the cooler night-time ambient temperature and preventing heat gain during the afternoon peak hours. Natural ventilation due to prevailing wind through the air-wells at nighttime (when all the facade openings are closed) could improve this stack effect (Chan, Riffat, and Zhu 2010). Use of multiple air-wells which facilitate cross ventilation is an effective design strategy to improve natural ventilation in the $\mathrm{CSH}$.

\section{Conclusion}

Climate responsive design strategies of vernacular architecture result from hundreds of years of optimization to provide a comfortable shelter in a local climate. The $\mathrm{CSH}_{\mathrm{A}}$ in Southeast Asia represents a climatic and socio-economic adaption from a subtropical to a tropical climate. The air-well type courtyard is used in the $\mathrm{CSH}$ to regulate the indoor thermal environment of intermediate spaces in a long narrow plan. This study investigates the effectiveness of the air-well type courtyard for indoor thermal environments in a tropical CSH. The study strengthens pervious research on the passive cooling potential attributed to increased shading in the air-well type courtyards. The cooling potential of wind induced ventilation through the air-well courtyard is apparent when the wind flows in parallel to the longer axis of the building and the intermediate spaces are cross-ventilated via several air-well courtyards. Wind induced ventilation could enhance the passive cooling due to the stack effect when multiple air-wells are used. Further research is needed to validate the effectiveness of wind induced ventilation through the air-well at different wind speeds and orientations.

The study has two limitations. First, the field measurement was conducted on one fair weather day. Although in tropical climates the temperature does not vary significantly day to day and 
month to month, more measurements on different days are considered to explore more nuanced thermal environments in the CSH. Second, this study only focuses on deep and closed air-well type shophouses. Kubota et al. (2017) classified five air-well type courtyards found in the CSH according to their forms and characteristics that affect the profiles of their thermal environments. The selected CSHs in this research represent the deep and closed air-well type (Type 5) which typically has lower daytime temperatures and higher night-time air temperature. This study needs to be extended to analyse the influence of other air-well typologies 1571 in the CSH and their combined influence on the effectiveness of cross ventilation through the air-well to improve the indoor thermal environment of the $\mathrm{CSH}$.

\section{Acknowledgements} Zhongqi, Zhu Dan, Fu Jiayan, Zhang Qianning, Ling Mengzhi and valuable comments received from Prof. Wang Li and Prof. Wang Jie.

\section{Disclosure statement}

1581 Q3 No potential conflict of interest was reported by the authors.

\section{Funding}

This work was supported by MOE Academic research fund (AcRF) of National

\section{References}

ASHRAE, ASHRAE Standard. 2013. "Standard 55-2013." Thermal Environmen-

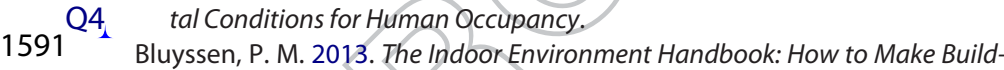
Q5 ings Healthy and Comfortable. Routledge.

Chan, H., S. B. Riffat, and J. Zhu. 2010. "Review of Passive Solar Heating and Cooling Technologies." Renewable and Sustainable Energy Reviews 14 (2): 781-789.

Q6 CIBSE. 2005. Natural Ventilation in Non-domestic Buildings. London.

1596Q7 Davison, J., and L. . Tettoni. 2011. Singapore Shophouses. Laurence King.

Firley, E., and C. Stahl. 2009. The Urban Housing Handbook. Chichester: Wiley.

Givoni, B. 1998. "Effectiveness of Mass and Night Ventilation in Lowering the Indoor Daytime Temperatures. Part I: 1993 Experimental Periods." Energy and Buildings 28 (1): 25-32.

1601

Hassan, A. S., and S. R. C. Yahaya. 2012. Architecture and Heritage Buildings in George Town. Penang: Penerbit USM.

Hoseini, G., A. Hosein, U. Berardi, N. D. Dahlan, and A. G. Hoseini. 2014. "What Can We Learn from Malay Vernacular Houses?" Sustainable Cities and Society 13: 157-170.
Special appreciation of students who participated in data collection: Yu 1586Q2 University of Singapore [Grant Number WBS No: R295000126112].
Jayasinghe, M. T. R., and R. A. Attalage. 1999. “Passive Techniques for Residential Buildings in Low Altitudes of Sri Lanka." Engineer, Journal of Institution of Engineers, Sri Lanka 29 (2): 18-27.

Karava, P. 2008. Airflow Prediction in Buildings for Natural Ventilation Design: Wind Tunnel Measurements and Simulation. Concordia University.

Khanal, R., and C. Lei. 2011. "Solar Chimney - A Passive Strategy for Natural Ventilation." Energy and Buildings 43 (8): 1811-1819.

Knapp, R., and A. C. Ong. 2013. Chinese Houses of Southeast Asia: The Eclectic Architecture of Sojourners and Settlers. Tuttle.

Kubota, T., and D. H. C. Toe. 2008. "Passive Cooling of Residential Buildings in Hot-humid Climate of Malaysia: Night Ventilation Technique." Proceedings in the 9th SENVAR+2nd ISESEE 2008 conference, Shah Alam, University Publication Centre.

Kubota, T., M. A. Zakaria, S. Abe, and D. Toe. 2017. "Thermal Functions of Internal Courtyards in Traditional Chinese Shophouses in the Hot-humid Climate of Malaysia." Building and Environment 112: 115-131.

Lomas, K. J. 2007. "Architectural Design of an Advanced Naturally Ventilated Building Form." Energy and Buildings 39 (2): 166-181. on the Thermal Comfort of Courtyard Typology for Italian Climate Zones." Sustainable Cities and Society 29: 97-106.

Moosavi, L., N. Mahyuddin, N. Ghafar, and M. A. Ismail. 2014. "Thermal Performance of Atria: An Overview of Natural Ventilation Effective Designs." Renewable and Sustainable Energy Reviews 34: 654-670.

Muhaisen, A. S. 2006. "Shading Simulation of the Courtyard Form in Different Climatic Regions." Building and Environment 41 (12): 1731-1741.

Olgyay, V. 2015. Design with Climate: Bioclimatic Approach to Architectural Regionalism. Princeton University Press.

Omar, N. A. M., and S. F. Syed-Fadzil. 2011. "Assessment of Passive Thermal Performance for a Penang Heritage Shop House." Procedia Engineering 20: 203-212.

Rajapaksha, I., H. Nagai, and M. Okumiya. 2003. "A Ventilated Courtyard as a Passive Cooling Strategy in the Warm Humid Tropics." Renewable Energy 28 (11): 1755-1778.

Sadafi, N., E. Salleh, L. C. Haw, and Z. Jaafar. 2011. "Evaluating Thermal Effects of Internal Courtyard in a Tropical Terrace House by Computational Simulation." Energy and Buildings 43 (4): 887-893.

Steadman, R. G. 1979. "The Assessment of Sultriness. Part I: A TemperatureHumidity Index Based on Human Physiology and Clothing Science." Journal of Applied Meteorology. 18 (7): 861-873.

Tan, C. B. 1988. The Baba of Melaka:Culture and Identity of a Chinese Peranakan Community in Malaysia. Pelanduk.

Toe, D., and T. Kubota. 2015. “Comparative Assessment of Vernacular Passive Cooling Techniques for Improving Indoor Thermal Comfort of Modern Terraced Houses in Hot-humid Climate of Malaysia." Solar Energy 114: 229-258.

Wang, H., and B. Jia. 2016. "Urban Morphology of Commercial Port Cities and Shophouses in Southeast Asia." Procedia Engineering 142: 189-196.

Zakaria, M. A., T. Kubota, and D. Toe. 2015. "The Effects of Courtyards on Indoor Thermal Conditions of Chinese Shophouse in Malacca." Procedia Engineering 121: 468-476.
Martinelli, L., and A. Matzarakis. 2017. "Influence of Height/Width Proportions

1621

Q8

1626

Q9

1631

Q10

1636

164

Q11.

1646

Q12

1656

1661

1666

1606 